\title{
Women Entrepreneurs and Bankruptcy: An Empirical Analysis in Italy
}

\author{
Ferdinando Giglio ${ }^{1}$ \\ ${ }^{1}$ Department of Economics, University of Campania "Luigi Vanvitelli", Capua, Italy \\ Correspondence: Ferdinando Giglio, PhD at University of Campania "Luigi Vanvitelli", Corso Gran Priorato di \\ Malta, 1, Capua, Italy, 81043.
}

Received: October 2, 2021

Accepted: October 21, 2021

Online Published: October 28, 2021

doi:10.5539/ijef.v13n12p24

URL: https://doi.org/10.5539/ijef.v13n12p24

\begin{abstract}
This work aims to estimate the probability of bankruptcy of female entrepreneurs in Italy, particularly in the Campania region.

Women who run businesses always continue to be disregarded by banks when applying for a loan due to several problems including: the small size of their companies and the low number of employees.

The companies were selected by Aida. Through the T-test the probability of bankruptcy of male and female companies was compared, however, the variables that have the greatest impact on gender were examined with the regression model. It was found that, albeit slightly, female entrepreneurs have a lower probability of failure than their male counterparts.
\end{abstract}

Keywords: business failure, women entrepreneurs, Z-score

\section{Introduction}

The financial crisis in 2007 brought with it major corporate failures rooted in the US subprime mortgage crisis.

Failure is usually viewed either as a balanced event of disruption (Peat, 2007) or as a process leading to any undesirable business outcome with a varying degree of purpose (Ooghe \& Prijcker, 2008).

The specific definition of bankruptcy has both theoretical and practical importance: if it is argued that bankruptcy is a sign of default, it must be argued that bankruptcy statistics are the best way to research it. However, it is easy to observe that: Failures do not include all failed business ventures, such as integrated startup projects, and not all interruptions are failures. Such is the case where there is no loss to creditors (Lussier, 1996), when the entrepreneur makes a profitable exit or the firm joins another. When the organizational entity comes to the end of its life, it is classified as a discontinued business, while stakeholders view it as a success.

Gulst and Maritz (2009) define failure as a deviation from the entrepreneur's desired expectations.

This definition creates relativity within the concept; failure becomes an interpretation as opposed to a fact.

Furthermore, since founders can interpret bankruptcy differently, similar events can be reported as bankruptcy and not as the case might actually be: in fact, classification attempts become difficult as it is not possible to establish a common definition of bankruptcy. . Based on this interpretative description, it is not possible to have a clear one.

Not only this, but the perception of failure or success can change over time as the entrepreneur's mind develops, not remaining stable even within the individual (Beaver, 2003). Clearly, whether or not failure has occurred becomes a matter of the entrepreneur's goals and motivations and, if taken into consideration, the views of different stakeholder groups who may judge the business as a success or a failure. For example, investors view failure in terms of negative investment returns (Zacharakis et al., 1999), while entrepreneurs use different criteria, including performance or personal satisfaction. Finally, the search for failure is interdisciplinary, united not necessarily by the same theoretical foundations, but by a common interest in the phenomenon. The researcher has his own theoretical biases: for example, organizational theorists are interested in finding different explanations for failure than scholars of strategic management, accounting or marketing (Rovenpor, 2004).

A study by Watson (2003) reveals that female entrepreneurs' failure rates are higher than those of men. Banks consider women to be less reliable than their counterparts and are therefore unwilling to offer them loans.

This is because numerous scholars (Hisrich \& Brush, 1984; Chell \& Baines, 1988; Birley, 1989; Sexton \& Bowman-Upton, 1990; Rosa et al., 1996; Cliff, 1998; Boden \& Nucci, 2000; Merrett \& Gruidl, 2000; Watson, 
2002; Westhead, 2003) found that female-owned companies have lower sales revenue, fewer employees, primarily serve local markets, and are less ambitious in growing their business.

The objective of this article is to calculate the probability of bankruptcy of companies led by entrepreneurs in Campania and compare it with that of men.

The work is divided as follows: after a review of the literature on the problems encountered by women entrepreneurs and on the Altman model, the methodology used and the main results obtained are presented. Finally, in the last part, we find the conclusions and the main limitations.

\section{Literature Review}

\subsection{Women Entrepreneurs' Problems}

Several studies show that female entrepreneurs continue to earn less than their counterparts and, moreover, are forced to face more obstacles (Davidson \& Burke, 2004; Fielden \& Davidson, 2005).

In recent decades, access to credit has been identified as one of the main problems holding back the growth and sustainability of SMEs, particularly female-owned businesses (Improving access to finance for women's ownership in India, 2014).

The conditions of access to a wide range of financial services are essential for the survival and development of businesses. Indeed, SMEs rely on bank credit considering it as their main source of financing as they are unable to access equity markets (Caglayon \& Xu, 2016; Inkloor et al., 2015; Kremp \& Sevestre. 2013; Mor \& Fink, 2013; Vermoesen et al., 2013).

Therefore, the question of access to credit is considered an important issue by politicians and researchers (Berger \& Udell, 2006; Cole \& Sokolyk, 2016; Kirschenmanon, 2016), given that SMEs rule the business landscape in Europe and are the main drivers of employment, development and innovation (Degryse \& Van Cayscele, 2000; Dekok et al., 2011; Popov \& Udell, 2012).

Significant literature points out that difficulties in accessing bank credit may be greater for women-led businesses, which affects their investment opportunities (World Bank, 2011).

This branch of literature analyzes such problems on both the demand and supply sides. On the demand side, several studies have found that female entrepreneurs are considered more risk averse than their male counterparts (Halt \& Luary, 2002; Eckel \& Grossman, 2008; Nellkonton, 2010; Yordanova \& Alexandrova-Boshnakova, 2011) and tend to refrain from borrowing as their penchant for being less secure may lead them to be more skeptical of their ability to obtain funding (Carter, Mwaura, Ram, Trehan, \& Jones, 2015; Choudhuri, Sasidharan, \& Ray, 2018; Crason \& Gneezy , 2009; Malmstram, Johansson, \& Wincent, 2017; Ongena \& Popov, 2016; Poczter \& Shapsis, 2018; Raper \& Scott, 2009; Treichel-Zimnerman \& Scott, 2006).

In financial markets, differences in risk attitudes can lead to inequalities in the approach to applying for external finance between male and female companies.

In the United States, Cavalluzzo et al. (2002) show that female businesses are more likely to avoid asking for credit because they believe that this market becomes more concentrated.

Robb and Walken (2002) note that women are more likely to borrow credit cards because they fear rejection on credit grounds.

Marlow and Carter (2006) note, however, that they tend to ask for less funding because, on the one hand, they prefer to run smaller firms and, on the other hand, they are more reluctant to take on debt (Carter \& Shaw, 2006).

For these reasons, female businesses are seen as discouraged debtors (Freel et al., 2012; Kolnins et al., 2014; Kon $\&$ Storey, 2003; Moro et al., 2017).

As regards the issue of gender discrimination on the supply side, the literature identifies two different types of discrimination: that of taste or prejudice - guided by preferences and beliefs not based on objective criteria - and that statistics - which manifests itself in the to gather costly information on the company's creditworthiness.

In these situations, the necessary information is provided by observing evident characteristics, such as gender (Aristei \& Gallo, 2016; Bellucci et al., 2010; Mascia \& Rossi, 2017). Several studies show that banks are more likely to favor male businesses because lenders have different perceptions about the potential of entrepreneurs (Alsos \& Ljunggren, 2017; Carter et al., 2007; Marlow \& Patton, 2005).

Female firms may face a higher rate of loan application rejection (Cavalluzzo et al., 2002), partial rejection by the lender (Krenel \& Yazdanfer, 2015; Treichel-Zimnerman \& Scott, 2006) and an obligation to pay more guarantees 
for the credit received (Alesina et al., 2013; Bellucci et al., 2010; Mascia \& Rossi, 2017; Muravyev et al., 2009; Wu \& Chua, 2012).

Use of survey data for the US National Survey of Small Business Finance reveals price discrimination (Cavalluzzo et al., 2002). Turning to testing outside the United States, Modill et al. (2006) find that Canadian female companies have shorter relationships with banks. Company survey data (BEEPS) in several countries, including some Eastern European and some Western European, also provide evidence of higher prices for female entrepreneurs (Muravyev et al., 2009).

Also in Italy, Alesina et al. (2012) found that female entrepreneurs pay higher interest rates than men.

\subsection{Altman's Model}

Business failure prediction models were initially based on the pioneering work of William Beaver. Beaver (1966) carried out a one-sided analysis, comparing the financial ratios of 79 failed and 79 non-bankrupt companies. His use of the paired sample approach and the use of a control sample to validate the model has been a benchmark for later researchers (Moghadam, Zodeh, \& Ford, 2011, p. 3).

A limitation of Beaver's work was the univariate nature of the model. By allowing only one report, he can provide inconsistent results for a company in case other reports are used. Not only this, but the financial complexity of a company cannot be captured by a single report. Finally, the cut-off point is chosen after the bankruptcy of a company, which means that, in reality, the bankruptcy state of a company must be predicted with consequent inaccurate classifications.

In 1968, Edward Altman advanced on Beaver's work by incorporating four other variables into the model to provide a more accurate overall prediction of the manufacturing company's failure. Altman's multidiscriminant analysis model differed from the Beaver model in relation to the ratios chosen for the highest prediction. Altman classifies companies into two mutually exclusive groups: bankrupt and non-bankrupt (Altman, 1968, p. 591). Altman's discriminant analysis has become a dominant model used in the literature on business failure prediction due to its simplicity and accuracy. His multi-discriminatory approach allowed him to develop the equation into a combination of five ratios consisting of liquidity, profitability, leverage, solvency and sales activity. The result of combining the ratios results in a discriminating score known as the " $Z$ score".

The equation of the Altman model is as follows:

$$
\begin{aligned}
& \mathrm{Z}=0.012 \mathrm{X}_{1}+0.014 \mathrm{X}_{2}+0.033 \mathrm{X}_{3}+0.006 \mathrm{X}_{4}+0.999 \mathrm{X}_{5} \\
& \mathrm{X}_{1}=\text { Working Capital } / \text { Total Assets } \\
& \mathrm{X}_{2}=\text { Retained Earnings / Total Assets } \\
& \mathrm{X}_{3}=\text { Earnings Before Interest and Taxes / Total Assets } \\
& \mathrm{X}_{4}=\text { Market Value of Equity / Book Value of Total Liabilities } \\
& \mathrm{X}_{5}=\text { Sales / Total Assets } \\
& \mathrm{Z}=\text { Altman Z-Score }
\end{aligned}
$$

These are financial ratios taken from the balance sheet. They are tools used to understand and monitor both the financial position and the performance of a company (Erdogan, 2013).

In general, indices measuring profitability, liquidity, leverage and solvency appear to be the most significant indicators (Altman, 2002) of business failure.

In interpreting the model in equation (1), with a $\mathrm{Z}$ score greater than 2.99 the company is considered financially sound, with a $\mathrm{Z}$ score of less than 1.8, however, the company is financially in difficulty. The gray area between 1.81 and 2.99 is referred to as the "zone of ignorance" due to the situation with an incorrect classification (Prevoo, 2007) and could face a financial risk that leads to financial difficulties (Azadinamin, 2012) .

In equations (2), (3), .. and (6), the variables $\mathrm{x} 1, \mathrm{x} 2, \ldots$ and $\mathrm{x} 5$ represent the metrics generated by the accounting reports. Metrics are a resistance of several forms of conventional relationships including liquidity, assets and debt ratios.

In equation (2), $\mathrm{x} 1$ measures the liquidity of companies in relation to their total assets. Liquidity ratios are used to examine a company's ability to meet its short-term financial claims (Abdullah \& Ismail, 2008; Ponikvar et al., 2009) and also to underestimate creditworthiness (Aysun, 2012) .

On the liquidity metric, Amoa-Gyarteng (2014) indicates that a troubled firm will keep a shrinking portfolio of 
current assets and therefore lower capital, which results in a low index.

The $\mathrm{x} 2$ and $\mathrm{x} 3$ metrics in equation (3) measure the profitability of the business. The indices exploit the overall efficiency of the firm and measure both the profit margin that the firm is able to generate and the return it provides on the structures and funds it finances it (Mary, 2012). Evidently, the most profitable companies have time to persuade them to use their work and have to wait longer for their credits (Ponikvar et al., 2009). The ratio of retained earnings to total assets indicates the extent to which the assets have been paid for by corporate profits (Ray, 2011). He argues that a low ratio indicates that growth is unsustainable as it is financed by increasing debt rather than reinvesting profits.

$\mathrm{X} 4$ in equation (5) indicates a measure of leverage. Leverage describes a company's financial structure and measures long-term risks (Abdullah \& Ismail, 2008). The leverage ratio, on the other hand, is an accepted measure of the additional risk placed on ordinary shareholders following the decision to finance debt operations (Caplan et al., 2012).

George and Hwang (2010) argue that if financial distress is costly and companies make optimal capital structure decisions, low-leveraged companies will be exposed to greater systematic risk than highly leveraged companies.

In equation (6), $x 5$ represents the activity ratio that marks sales and activities. Activity ratios are used to estimate the efficiency with which it manages and uses its assets (Pandey, 1999). Therefore, if the firm has a low ratio of sales to activity, it is implied that there is an underutilization of the activities or, alternatively, that the resources are not being used efficiently (Glautier \& Underdown, 2011).

Sanesh (2016) tried to underestimate the z-score of Nifty 50 companies excluding banks and financial firms. The score tries to predict the probability of companies defaulting due to financial difficulties based on current statistics.

Kumari's (2013) article tried to fail for MMTC based on Altman's model. He concluded by stating that MMTC's financial health is good and it can be considered an investor-friendly company. Also relevant are the works of Ramona and Hari (2013). The analysis carried out shows the poor financial performance that led to the bankruptcy of the Chittoor sugar cooperative.

Vikas (2014) studied the financial health of the logistics sector in India using Altman's z-score. He reveals that the Indian industry was healthy. It is good that the z-score average increased from 2006 to 2010 (as the Indian economy was hit by the global recession.

Al-Rawi, Kiani, and Vedd (2008) used Altman's analysis to predict the insolvency of a firm. They noted that the company has owed its debt and will face bankruptcy in the near future.

Chowdhury and Barua (2009) applied this model to class z shares traded in DSE to judge the risk of financial difficulty of each share. They used data from 53 companies from the years 2000-2005 to calculate the z-score. They argued that Altman's z-score model, while it may not be applicable for companies in Bangladesh, demonstrates its strong validity and fairness in predicting the suffering status of the z-category company.

Ramaratnam and Jayaraman (2010) measured the financial strength of the Indian steel industry. The study was based on five-year (2006-2010) data from five companies in the steel industry. Their study revealed that all the selected companies were financially sound during the period considered.

Similarly, Pathan (2009) applied this model to a sample of US bank holdings over the period 1997-2004 and found that small board sizes lead to additional banking risk.

Ko et al. (2016) used Altman's model to determine the financial performance of solar energy companies in Taiwan. For the empirical analysis, data from the period 2009-2014, taken from the database of the Taiwan Economic Journal, were used. The results show that companies in financial difficulty suffer a decline in profitability.

In the study conducted in the Republic by Rybarova et al. (2016), the financial failures of companies were determined using a 2013 dataset of 109 players in the Slovakian construction sector. The operators analyzed were the companies with a turnover of more than 10 million euros. The results show that these companies are healthy.

Yilman and Yildiron (2015) wanted to test the estimation capacity of the Altman z-score method with financial data for the years 2001-2006 for 18 failed and 18 successful companies listed in the BIST. companies' financial ratios and values, it is estimated how close each company is to bankruptcy. Then, these estimates were compared with actual BIST data. In these comparisons, it was found that the Altman z-score estimated 16 out of 18 successful companies and 10 out of 14 unsuccessful companies.

Civan and Dayi (2014) aimed to measure the financial failures of enterprises with data for 2008-2012 of health enterprises affiliated to the Union of Public Hospitals of Zanguldak. The z-score method was applied to the dataset. 
The number of unsuccessful businesses is estimated to be $4 \%$ and businesses with a $95 \%$ probability of failure within one year to be $27 \%$.

Yildiz (2014) determined Altman z-score values using the financial dataset of 35 companies in the BIST-100 index. Furthermore, by incorporating the corporate governance index, a dual logistic regression method was used to determine the investable or non-investable status of the companies. In this study, it was determined that there was a relationship between the investable positions of the companies and the Altman s-scores.

Mohana (2015) examined the state of financial difficulty of listed companies in Ghana. The study sampled 10 listed companies which study results showed 6 solid companies with no financial survival.

\section{Data and Methodology}

The companies have been selected by Aida, a database that allows the search, consultation, analysis and processing of economic-financial, personal and commercial information of all joint-stock companies operating in Italy.

In particular, the selected sample is made up of 1518 companies present in the Campania region.

The t-test was performed to analyze the probability of business failure by women entrepreneurs compared to their counterparts.

The multiple regression model, on the other hand, was done to see which variables impact the best on gender. In particular, four variables were examined in the regression model: the structural margin, the debt ratio, the operating cash flow and the liquidity ratio.

The structural margin highlights the difference between own capital and fixed assets.

The debt ratio is an index that relates the capital borrowed from third parties with that of one's own.

The operating cash flow indicates the positive or negative changes in the company's liquidity that are recorded in a given period of time, generally one year.

Finally, the current liquidity index highlights the company's short-term capacity with immediate liquidity and with financial and economic activities.

\section{Results}

Looking at Figure 1, it can be deduced that $31.10 \%$ of the sample is represented by female businesses while $68.90 \%$ by companies led by entrepreneurs.

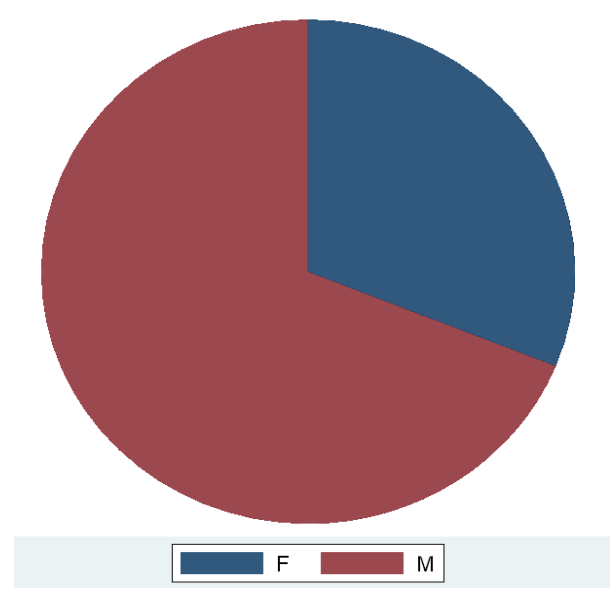

Figure 1. Percentage of men and women

Before carrying out the t-test, to see if the probability of bankruptcy of female firms is equal to that of men, a comparison was made between the variables present in the Altman discriminating function between male and female firms (see table 1) and it was found that, with regard to the first variable (x1), the value of liquid assets with respect to the total capitalization of female businesses is greater than that of men $(0.271 \mathrm{vs} 0.172)$.

Regarding the second variable (x2), female entrepreneurs have a greater ability to reinvest their profits than their male counterparts $(0.035$ vs 0.026$)$.

With respect to the third variable (x3), it was found that female enterprises have a lower productivity than male enterprises $(36,403$ vs 37,028$)$. 
With regard to the fourth variable $(\mathrm{x} 4)$, women entrepreneurs have a higher level of financial leverage than that of entrepreneurs (0.701 vs 0.463 ).

Finally, with respect to the fifth variable (x5), female enterprises have a greater ability to generate results than male enterprises (1.158 vs 1.123$)$.

Table 1. Comparison of values between men and women

\begin{tabular}{lccccc}
\hline & mean_x1 & mean_x2 & mean_x3 & mean_x4 & mean_x5 \\
\hline Women & .271 & .035 & 36.403 & .701 & 1.158 \\
Men & .172 & .026 & 37.028 & .463 & 1.123 \\
\hline
\end{tabular}

Table 2 reports the data obtained after carrying out the $t$ test.

Two hypotheses have been formulated:

$\mathrm{H}_{0}$ : the probability of failure between female and male firms is the same.

$\mathrm{H}_{1}$ : the probability of bankruptcy between female and male firms is different.

Carried out the $\mathrm{t}$ test, it was found that, even if slightly, the probability of bankruptcy of companies led by female entrepreneurs is lower than that of their male counterparts (38.568 vs 38.812).

Table 2. T-test

\begin{tabular}{ccccccccc}
\hline & obs1 & obs2 & Women & Men & dif & St Err & t value & $p$ value \\
\hline z by dummygenere: $\sim 1$ & 576 & 260 & 38.568 & 38.812 & -.244 & 2.66 & -.1 & .927 \\
\hline
\end{tabular}

Table 3 shows the results obtained from the regression.

The regression model was used to see which variables impact the risk probability of female firms.

The dependent variable used in the regression model is $\mathrm{Z}$. The independent variables, on the other hand: the structure margin, the debt ratio, the operating cash flow and the current liquidity ratio.

I have been formulating 4 hypotheses:

$\mathrm{H}_{1}$ : the structural margin influences the probability of bankruptcy of female businesses

$\mathrm{H}_{2}$ : the debt ratio influences the probability of bankruptcy of female businesses

$\mathrm{H}_{3}$ : management cash flow influences the probability of bankruptcy of female businesses

$\mathrm{H}_{4}$ : the current liquidity ratio influences the probability of bankruptcy of female businesses

Table 3. Regression model

\begin{tabular}{|c|c|c|c|c|c|c|}
\hline VARIABLES & $\begin{array}{c}(1) \\
\text { model } \\
\end{array}$ & $\begin{array}{c}(2) \\
\text { model } \\
\end{array}$ & $\begin{array}{c}(3) \\
\text { model } \\
\end{array}$ & $\begin{array}{c}(4) \\
\text { model } \\
\end{array}$ & $\begin{array}{c}(5) \\
\text { model }\end{array}$ & $\begin{array}{c}(6) \\
\text { model } \\
\end{array}$ \\
\hline Dummy genere & $\begin{array}{l}-25.23 \\
(27.72)\end{array}$ & $\begin{array}{c}2.093 \\
(1.761)\end{array}$ & $\begin{array}{c}2.093 \\
(1.761)\end{array}$ & $\begin{array}{l}0.0799 \\
(2.668)\end{array}$ & $\begin{array}{c}2.612 \\
(3.370)\end{array}$ & $\begin{array}{c}2.330 \\
(2.023)\end{array}$ \\
\hline Debt ratio & & $\begin{array}{c}0.210^{* * *} \\
(0.0783)\end{array}$ & $\begin{array}{c}0.210^{* * *} \\
(0.0783)\end{array}$ & & & \\
\hline Structure margin & & $\begin{array}{c}0.00372 \\
(0.00382)\end{array}$ & $\begin{array}{c}0.00372 \\
(0.00382)\end{array}$ & & & \\
\hline Roa & & $\begin{array}{c}4.867 * * * \\
(0.154)\end{array}$ & $\begin{array}{c}4.867 * * * \\
(0.154)\end{array}$ & & & \\
\hline Main activity & $\begin{array}{c}7.739 \\
(5.421)\end{array}$ & & & & & \\
\hline Middle age & $\begin{array}{l}-1.389 \\
(0.935)\end{array}$ & & & & & \\
\hline Liquidity index & & & & $\begin{array}{c}3.578^{* *} \\
(1.781)\end{array}$ & & \\
\hline
\end{tabular}




\begin{tabular}{|c|c|c|c|c|c|c|}
\hline Current index & & & & $\begin{array}{c}-4.548 * * * \\
(1.565)\end{array}$ & & \\
\hline Cash flow from management & & & & $\begin{array}{c}2.83 \mathrm{e}-05^{* * *} \\
(7.46 \mathrm{e}-06)\end{array}$ & & \\
\hline Debt/Equity ratio & & & & & $\begin{array}{l}-0.771 \\
(0.506)\end{array}$ & \\
\hline Cost of borrowing & & & & & $\begin{array}{c}0.777^{*} * \\
(0.311)\end{array}$ & \\
\hline Property coverage index & & & & & $\begin{array}{l}-0.00800 \\
(0.0197)\end{array}$ & \\
\hline Indep. Degree from third parties & & & & & & $\begin{array}{c}-0.676^{* *} \\
(0.325)\end{array}$ \\
\hline Roe & & & & & & $\begin{array}{c}0.806 * * * \\
(0.0451)\end{array}$ \\
\hline Ros & & & & & & $\begin{array}{c}1.024 * * * \\
(0.146)\end{array}$ \\
\hline Constant & $\begin{array}{c}81.74 \\
(52.07)\end{array}$ & $\begin{array}{c}14.37 * * * \\
(1.395)\end{array}$ & $\begin{array}{c}14.37 * * * \\
(1.395)\end{array}$ & $\begin{array}{c}41.19 * * * \\
(2.257)\end{array}$ & $\begin{array}{c}36.03 * * * \\
(2.710)\end{array}$ & $\begin{array}{c}27.42 * * * \\
(1.345)\end{array}$ \\
\hline Observations & 26 & 823 & 823 & 811 & 491 & 787 \\
\hline R-squared & 0.147 & 0.562 & 0.562 & 0.029 & 0.021 & 0.437 \\
\hline
\end{tabular}

$\mathrm{H}_{1}$ : The structural margin influences the probability of bankruptcy of female businesses.

The structural margin does not influence the probability of bankruptcy of female businesses. Positive companies have a structural margin, they are able to fully finance lasting investments, without resorting to any form of debt. Companies can also implement business development strategies and implement business expansion operations. Having a positive structural margin allows equity capital to fully finance fixed assets.

$\mathrm{H}_{2}$ : The debt ratio influences the probability of bankruptcy of female businesses.

The debt ratio has an impact on the probability of bankruptcy of female businesses.

Companies with a high ratio will tend to use loans to cover operating costs, making them more exposed to risk during a crisis or should interest rates rise. Furthermore, companies are too exposed to third parties: this signals bad business management. This implies the need to withdraw more financial resources in order to be able to tell the stakeholders, which must be remunerated with the payment of interest.

$\mathrm{H}_{3}$ : Management cash flow influences the probability of bankruptcy of female businesses.

The cash flow management influences the probability of bankruptcy of female businesses.

Companies, which do not constantly plan cash flows, find themselves in situations of illiquidity that even come to undermine their very survival. A negative cash flow is an indication that the company is unable to meet payments with its own liquidity.

$\mathrm{H}_{4}$ : The current liquidity index the probability of bankruptcy of female businesses.

The current liquidity ratio has an impact on the probability of bankruptcy of female businesses.

This implies that companies are not using their assets and capital efficiently. Furthermore, companies with a high index are unable to meet their short-term debts with the financial resources already available or that will be in the future.

Therefore, only the first hypothesis is not verified; the other three do.

\section{Conclusions and Limitations}

The paper analyzed the various problems that women entrepreneurs find themselves facing, that of access to credit. The analysis was conducted on a sample of companies located in the Campania region.

The research found that businesses led by female entrepreneurs, albeit slightly, are less likely to fail than male businesses.

Hence, it can be inferred that women are discriminated against by banks by different lenders. Research shows that women's businesses suffer a double form of discrimination. 
Firstly, being smaller and specialized in less productive sectors, they are less attractive to investors. Furthermore, businesses run by women are perceived as more risky for a cultural demand. The result is that the applications for financing by women entrepreneurs are often not accepted and when they are, compared to men, they find themselves paying higher interests and having to accept more stringent conditions.

The work also has several limitations.

First of all, only the companies located in Campania were examined. A comparison could be made between southern and northern firms, thus enlarging the sample.

Furthermore, only four variables were examined: debt ratio, structural margin, current liquidity ratio and operating cash flow. Other variables could be added in the regression model.

\section{References}

Akehurst, G., Simarro, E., \& Mas Tur, A. (2012). Women entrepreneurship in small service firms: Motivations, barriers and performance. Service Industries Journal, 32(15), 2489-2505. https://doi.org/10.1080/02642069.2012.677834

Alesina, A. F., Lotti, F., \& Mistrulli, E. (2013). Do women pay more for credit? Evidence from Italy. Journal of the European Economic Association, 11(SUPPL. 1), 45-66. https://doi.org/10.1111/j.1542 4774.2012.01100.x

Asiedu, E., Kalonda, K. I., Ndikumana, L., \& Nti, A. A. (2013). Access to credit by firms in sub Saharan Africa: How relevant is gender? American Economic Review, 103(3), 293-297. https://doi.org/10.1257/aer.103.3.293

Aterido, R., Beck, T., \& Iacovone, L. (2013). Access to Finance in Sub Saharan Africa: Is There a Gender Gap? World Development, 47, 102-120. https://doi.org/10.1016/j.worlddev.2013.02.013

Baidoo, S. T., Sakyi, D., \& Aidoo, B. (2020). Does gender matter in credit denial among small and medium scale enterprises in Ghana? International Journal of Entrepreneurship and Small Business, 39(3), 339-362. https://doi.org/10.1504/IJESB.2020.104980

Beck, T., Behr, P., \& Madestam, A. (2018). Sex and credit: Do gender interactions matter for credit market outcomes? Journal of Banking and Finance, 87, 380-396. https://doi.org/10.1016/j.jbankfin.2017.10.018

Charness, G., \& Gneezy, U. (2012). Strong Evidence for Gender Differences in Risk Taking. Journal of Economic Behavior and Organization, 83(1), 50-58. https://doi.org/10.1016/j.jebo.2011.06.007

De Mel, S., McKenzie, D., \& Woodruff, C. (2009). Are women more credit constrained? Experimental evidence on gender and microenterprise returns. American Economic Journal: Applied Economics, 1(3), 1-32. https://doi.org/10.1257/app.1.3.1

Eckel, C. C., \& Grossman, J. (2008). Forecasting risk attitudes: An experimental study using actual and forecast gamble choices. Journal of Economic Behavior and Organization, 68(1), 1-17. https://doi.org/10.1016/j.jebo.2008.04.006

Garwe, D. K., \& Fatoki, O. (2012). The impact of gender on SME characteristics and access to debt finance in South Africa. Development Southern Africa, 29(3), 448-461. https://doi.org/10.1080/0376835X.2012.706040

Le, L. H., \& Stefańczyk, K. (2018). Gender discrimination in access to credit: A re women led SMEs rejected more than men led?. Gender, Technology and Development, 22(2), 145-163. https://doi.org/10.1080/09718524.2018.1506973

Madill, J. J., Riding, A. L., \& Haines, H. (2006). Women Entrepreneurs: Debt Financing and Banking Relationships. Journal of Small Business and Entrepreneurship, 19(2), 121-142. https://doi.org/10.1080/08276331.2006.10593363

Mohammed, S. (2016). Bankruptcy Prediction by Using the Altman Z-score Model in Oman: A Case Study of Raysut Cement Company SAOG and its subsidiaries. Australasian Accounting, Business and Finance Journal, 10(4), 70-80. https://doi.org/10.14453/aabfj.v10i4.6

Nwosu, E. O., \& Orji, A. (2016). Access to formal credit and enterprise performance in Nigeria: A gender perspective. Argumenta Oeconomica, 36(1), 191-224. https://doi.org/10.15611/aoe.2016.1.08

Ongena, S., \& Popov, A. (2016). Gender Bias and Credit Access. Journal of Money, Credit and Banking, 48(8), 1691-1724. https://doi.org/10.1111/jmcb.12361

Presbitero, A. F., Rabellotti, R., \& Piras, C. (2014). Barking up the Wro ng Tree? Measuring Gender Gaps in Firm's Access to Finance. Journal of Development Studies, 50(10), 1430-1444. https://doi.org/10.1080/00220388.2014.940914 
Sackey, F. G., \& Amponsah, N. (2018). Gender discrimination in commercial banks' credit markets in Ghana: A deco mposition and counterfactual analysis. African Journal of Business and Economic Research, 13(2), 121-140. https://doi.org/10.31920/1750 4562/2018/v13n2a6

Treichel, M. Z., \& Scott, J. (2006). Women owned businesses and access to bank credit: Evidence from three surveys since 1987. Venture Capital, 8(1), 51-67. https://doi.org/10.1080/13691060500453726

Verheul, I., \& Thurik, R. (2001). Start Up Capital: “Does Gender Matter?” Small Business Economics, 16(4), 329-346. https://doi.org/10.1023/A:1011178629240

Zegarra, L. F. (2013). Women and credit in peru during the guano era. Was there gender discrimination in the mortgage credit market of peru? Revista de Historia Economica Journal of Iberian and Latin American Economic History, 32(1), 151-185. https://doi.org/10.1017/S0212610914000020

\section{Copyrights}

Copyright for this article is retained by the author(s), with first publication rights granted to the journal.

This is an open-access article distributed under the terms and conditions of the Creative Commons Attribution license (http://creativecommons.org/licenses/by/4.0/). 